\title{
Dlaczego wierzymy w fake newsy? \\ Techniki wpływu społecznego i dezinformacja w dobie pandemii COVID-19
}

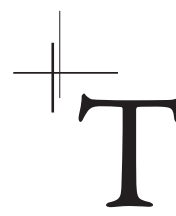

Trwająca od marca 2019 roku pandemia koronawirusa SARS-CoV-2 wpłynęła właściwie na każdą dziedzinę ludzkiego życia. Towarzysząca jej izolacja, która w chwili powstawania tego tekstu trwa od ponad roku, miała za zadanie ograniczyć rozprzestrzenianie się zarazy, a tym samym obniżyć ryzyko zachorowania na COVID-19 (Nanotkar, Dhanvij i Joshi 2020; Qian i Jiang 2020). Warto jednak pamiętać, że poza ryzykiem związanym z samą chorobą, pandemia i spowodowany nią lęk otworzyły drzwi na nasilone rozprzestrzenianie dezinformacji i tak zwanych fake newsów. Sam Tedros Adhanom Ghebreyesus, dyrektor generalny Światowej Organizacji Zdrowia (WHO), w lutym 2020 roku w trakcie konferencji w Monachium problem ten skomentował następująco: „Nie walczymy jedynie z pandemią, walczymy również z infodemią" (Zarocostas 2020: 676). Zdaje się to $\mathrm{w}$ istocie obrazować powagę sytuacji związaną z rozprzestrzenianiem się przekazów przedstawiających zniekształconą wizję rzeczywistości, skłaniać do refleksji nie tylko nad nieodłącznymi konsekwencjami, lecz także mechanizmami, które sprawiają, że z taką łatwością ulegamy fałszywym informacjom.

\section{Pandemiczny fake news w literaturze}

Choć sama pandemia i towarzysząca jej „infodemia” nadal trwają i są stosunkowo nowymi zjawiskami, szybko stały się tematem licznych badań i publikacji. Niektóre zagraniczne opracowania proponują wykorzystanie dorobku nauk społecznych do zwalczania chaosu informacyjnego (van Bavel i in. 2020; van der Linden, Roozenbeek i Compton 2020). Można się także spotkać z ujęciem fake newsów z perspektywy różnic indywidualnych. Badanie Alvi i Saraswat (2020) dotyczy związków między cechami osobowości i różnicami indywidualnymi oraz skłonnościami do ulegania heurystykom myślenia, co skutkuje większą podatnością na wiarę w fake newsy i częstszym udostępnianiem ich na portalach społecznościowych. 
Greene i Murphy (2020) rozpatrują z kolei zagadnienie różnic indywidualnych w perspektywie podatności na powstawanie fałszywych wspomnień spowodowanych fałszywymi informacjami związanymi z pandemią. Wiele opracowań, w tym także polskich publikacji, wskazuje najpopularniejsze fake newsy rozpowszechniane w czasie pandemii (Bieniek 2020; Jaśkowiec 2020; Moscadelli i in. 2020). Autorzy podkreślają powagę niebezpieczeństw, które wynikają z fałszywych informacji, i apelują, że interwencja portali społecznościowych jest niezbędna do zahamowania fali fake newsów (Moscadelli i in. 2020). Jak piszą van der Linden, Roozenbeek i Compton (2020), póki co niewiele uwagi poświęcono fałszywym informacjom z perspektywy społecznej i behawioralnej, pomimo takich źródeł jak van Bavel i in. (2020). Choć wskazywane są rozwiązania, które mogłyby ograniczyć rozprzestrzenianie pandemicznych fake newsów, to brakuje źródeł, które podejmowałyby zagadnienie, analizując społeczne mechanizmy, na których opierają się fałszywe wiadomości. Właśnie tę lukę ma za zadanie wypełnić poniższy tekst.

\section{Fake news i dezinformacja}

„Termin «fake news» («fałszywe wiadomości») jest neologizmem i trudno go umieścić w definicyjnych ramach. Oznacza wiadomość medialną, która jednocześnie nie jest ani prawdą, ani kłamstwem, opiera się na dezinformacji, często zawierając fragmenty prawdziwe" (Bąkowicz 2019: 281) ${ }^{1}$. Stownik języka polskiego PWN 'fake newsy' definiuje następująco: „nieprawdziwe, fałszywe wiadomości, najczęściej rozpowszechniane przez tabloidy w celu wywołania sensacji bądź zniesławienia kogoś (najczęściej polityka)”. Antos (2019) podkreśla także, że termin ten pojawił się już w 2005 roku w kontekście politycznych programów rozrywkowych, a od tego czasu uznano, że fałszywe wiadomości (fake news) mogą wywoływać wielorakie skutki w środkach masowego przekazu, w internecie, a zwłaszcza w polityce, które tak samo kształtują sposób postrzegania informacji przez opinię publiczną, postawy i zachowania (społeczne i polityczne) wyborców. Mimo zdefiniowania zjawiska niemalże dwie dekady temu dziś jego skala przerosła wszelkie wyobrażenia. Internet i media społecznościowe stały się głównym źródłem czerpania informacji, szczególnie wśród osób młodych, a tempo napływania wiadomości zdaje się stale przyspieszać (Król, Trybuła 2019; Cuan-Baltazar i in. 2020). To wszystko sprawia, że skala rozprzestrzeniania tychże „alternatywnych faktów” jest wręcz nieporównywalna $\mathrm{z}$ ich obecnością w momencie definiowania pojęcia fake newsów.

Choć sam termin 'fake news' można uznać za stosunkowo nowy, to nieodłącznie wiąże się on z pojęciem dezinformacji, która zazwyczaj jest jego skutkiem. Jej początki z kolei sięgają starożytności, kiedy to traktowana była jako zdolność oszukania wroga przez wybitnego i charyzmatycznego wodza (Bieniek 2020). Od tego czasu wykorzystywanie dezinformacji głównie w celach politycznych nie straciło popularności, a jej istotne przejawy można zaobserwować również dziś jako wypadkowe rozprzestrzeniania fałszywych informacji. Świerczek (2017: 211) wskazuje następującą definicję dezinformacji: „celowo fałszywa informacja, która ma wpłynąć na określoną grupę ludzi lub całą populację”. Dodaje także: „[...] istotą dezinformacji jest prowokacja, a nie kłamstwo [...]; państwa używają swych wywiadów do malowania obrazu prowokującego przeciwnika do podejmowania błędnych ocen" (Świer-

1 W tekście zastosowane będzie tłumaczenie pojęcia “fake news' jako „fałszywa wiadomość” z uwagi na to, że najczęściej pojawia się ono w literaturze przedmiotu (por. Iwasiński 2018; Bąkowicz 2019; Palczewski 2019). Ponadto nie sugeruje ono intencjonalności zmylenia odbiorcy przekazu, co pozwala na posługiwanie się szerszą definicją tego zjawiska (Palczewski 2019). 
czek 2017: 211). Nie sposób zatem nie zauważyć swoistych sprzężeń zwrotnych między fake newsami a dezinformacją. Te pierwsze mogą się stać doskonałym narzędziem do rozprzestrzeniania dezinformacji, z kolei im bardziej się ona nasila, tym większe stwarza podłoże do powstawania nowych fałszywych informacji, a w efekcie tym trudniejsze staje się także odróżnienie ich od tych wiarygodnych.

\section{Dlaczego wierzymy w fake newsy?}

Nasuwa się jednak podstawowe pytanie: co sprawia, że z taką łatwością ulegamy fake newsom i z taką szybkością zaczynamy traktować je jak prawdę? Choć odpowiedź na to pytanie jest nieco bardziej złożona, dominującą rolę odgrywają różnorakie mechanizmy społeczne, które zostaną omówione w dalszej części.

\section{Potrzeba domknięcia poznawczego}

Okoliczności związane z wybuchem pandemii COVID-19, a szczególnie jej początkowe tygodnie, dla wszystkich były czymś nowym i nieprzewidywalnym, co przyczynia się do pogorszenia efektywności filtrowania informacji (Landucci i Lamperti 2020). Można jednak wskazać także pewne predyspozycje osobowościowe, które sprawiają, że niektórzy chętniej i szybciej „chwytają się” fake newsów. Jako ich przykład przytoczyć można silną potrzebę domknięcia poznawczego. Wojciszke (2011: 62) definiuje to następująco: „Silny motyw domknięcia oznacza pragnienie, aby jak najszybciej mieć za sobą przetwarzanie informacji i dojść do nawet pochopnych wniosków, których człowiek gotów jest potem kurczowo się trzymać”. Kossakowska (2003: 355) natomiast o osobach z silnym motywem domknięcia poznawczego pisze: „Osoba charakteryzująca się wysoką potrzebą domknięcia w każdej sytuacji społecznej preferuje porządek i przewidywalność, łatwo podejmuje decyzje, jest zamknięta poznawczo (closed-minded) i odczuwa dyskomfort w obliczu wieloznaczności. Wysoki poziom potrzeby poznawczego domknięcia sprzyja powierzchownej analizie dopływających informacji, motywuje do poszukiwania informacji odpowiadających istniejącym już strukturom wiedzy. Powstały w wyniku tego procesu obraz sytuacji jest często uproszczony, zapewnia jednak poczucie jednoznaczności, przewidywalności i uporządkowania świata. Jest także odporny na zmianę". Tym samym zwracają uwagę, że dla osób o silnej potrzebie domknięcia poznawczego rozpoznawanie fake newsów będzie jeszcze trudniejsze. Ponadto, gdy taka fałszywa informacja trafi do nich przed wiadomością wiarygodną, szanse na weryfikację poglądów są niewielkie, co wynika ze swoistej wygody korzystania z najłatwiej dostępnych wyjaśnień.

\section{Techniki wpływu społecznego}

Zagadnienie szeroko pojętego wpływu społecznego pojawiało się w pracach różnych autorów, jednak za najbardziej uznanego twórcę i największy autorytet w tej dziedzinie bez wątpienia uważa się Roberta Cialdiniego (Doliński 2005). Jak pisze Doliński (2005: 30): „[Cialdini] Przez lata nie tylko studiował literaturę na ten temat i przeprowadzał naukowe eksperymenty w tym obszarze psychologii, ale także angażował się do pracy w miejscach, w których praktycy wpływu społecznego wdrażali najróżniejsze sztuczki, by osiągnąć swoje cele [...]”. Z tego powodu analiza zjawiska fake newsów będzie opierała się właśnie na tej koncepcji. Cialdini (2003: 12-13) - autor bestsellerowej książki Wywieranie wptywu na ludzi. Teoria i praktyka - pisze: „choć techniki wywierania wpływu na innych przyjmować mogą tysiące różnych postaci, większość daje się zaklasyfikować do jednej z sześciu podstawowych kategorii. 
[...] Sześć najważniejszych reguł to reguła wzajemności, konsekwencji, społecznego dowodu słuszności, lubienia, autorytetu i niedostępności”. Reguły te w wielu przypadkach stanowią także podstawowy mechanizm uwiarygodnienia fake newsów w oczach odbiorcy, a uległość względem takich informacji zachodzi w sposób automatyczny i bezrefleksyjny. Choć pierwsze wydanie wskazanej pozycji pochodzi z 1984 roku, a więc niemalże sprzed czterech dekad, można powiedzieć, że Cialdini doskonale przewidział skutki, jakie użycie tych technik może wywołać: „wskutek zalewającej współczesnego człowieka coraz większej fali informacji i wyborów rola takich automatycznych, bezrefleksyjnych mechanizmów ulegania wpływowi społecznemu będzie rosła w przyszłości” (Cialdini 2003: 13). Oddaje to doskonale obecne realia, które zgodnie z zapowiedzią badacza, dziś dają doskonałe podłoże dla rozprzestrzeniania dezinformacji i fake newsów. Wpływ wskazanych technik najlepiej zaobserwować można, analizując niektóre z najpowszechniejszych fałszywych informacji związanych z pandemią.

\section{Najczęstsze fake newsy w dobie pandemii}

Wraz z rosnącą w zawrotnym tempie liczbą zachorowań, szczególnie na początku pandemii, rosnąć zaczęła także ilość informacji i doniesień związanych z przewidywanym rozwojem sytuacji, zarówno zza granicy, jak i w obrębie kraju. Ogrom napływających fałszywych informacji był tak przytłaczający i trudny do opanowania, że uruchomiono specjalne strony internetowe poświęcone dementowaniu fake newsów, takie jak fakenews.pl, czy odpowiednią zakładkę na stronie rządowej, która umożliwia internautom zgłaszanie zaobserwowanych fałszywych wiadomości (www.gov.pl/web/koronawirus/zglos-fake-news). Przekazy te dotyczyły najróżniejszych tematów, od teorii związanych z powstaniem koronawirusa, obostrzeniami, które mogą się pojawić, aż po liczne porady, jak przed zarażeniem można się uchronić (Jaśkowiec 2020; Rzymski 2020). Równocześnie nasilający się lęk spowodowany koniecznością odnalezienia się w nowej, nieznanej sytuacji dodatkowo popychał do licznych zachowań konformistycznych, które przejawiały się większą ufnością względem cudzej oceny sytuacji (Troisi 2020). Wynika to z informacyjnej funkcji konformizmu, która wiąże się z wiarą w słuszność cudzych zachowań. Aronson (1995: 253) tłumaczy to w następujący sposób: „wpływ innych ludzi, który prowadzi nas do konformizmu, ponieważ spostrzegamy te osoby jako źródło informacji, dające wskazówki dla naszego zachowania; dostosowujemy się, ponieważ wierzymy, że cudza interpretacja niejasnej sytuacji jest bardziej poprawna niż nasza”. Doliński (2005: 199) z kolei w temacie wpływu lęku na podatność względem perswazji pisze: „Zdecydowana większość badań dotyczących związku między lękiem a skutecznością komunikatów perswazyjnych wskazuje na istnienie związku prostoliniowego: im silniejszy lęk, tym komunikat skuteczniejszy. Skuteczność takich komunikatów uwarunkowana jest jednak najczęściej tym, czy jasno mówią one, w jaki sposób można uniknąć zagrożenia”. Wszystkie te czynniki sprawiły, że w zetknięciu z fałszywymi informacjami, dodatkowo wzbogaconymi technikami wpływu społecznego, często nie sposób było w porę odróżnić fake newsa od prawdy.

\section{„Koleżanka dziennikarka” i stan wyjątkowy}

Gdy w połowie marca ubiegłego roku rozpoczęło się stopniowe wprowadzanie obostrzeń, natychmiast pojawiać zaczęły się różnorakie spekulacje związane z kolejnymi etapami lockdownu. Zalecenie pozostania w domu ograniczyło komunikację twarzą w twarz, a kontakt z innymi przeniósł się w dużej mierze na takie komunikatory jak Messenger, WhatsApp i inne 
(Naeem i Bhatti 2020). Nie trzeba było długo czekać, by za pośrednictwem tych aplikacji rozsyłane zaczęły być tak zwane „łańcuszki” związane z pandemią — wiadomości przekazywane do jak największej liczby osób, których zasięgi potrafią być zdumiewające. Jako jeden z nich można wskazać trwające około dwóch minut nagranie głosowe, w którym mężczyzna przekazuje „informacje” rzekomo uzyskane z wysoce wiarygodnych źródeł (Orzeł 2020). Treść nagrania była następująca:

Słuchajcie, mam koleżankę, która jest dziennikarką w Warszawie. Napisała informację: mam potwierdzone info z wielu niezależnych źródeł: ludzi blisko ABW i ONZ, ludzi blisko rządu, urzędników państwowych — chociaż niższego szczebla, od jednej znanej osoby i na stanowisku kierowniczym w spółce państwowej, że od niedzieli w poniedziałek zostanie ogłoszony stan wyjątkowy i zostaną pozamykane miasta, województwa. Będzie zakaz przemieszczania się, w tym też nakaz siedzenia w domu, wychodzenia tylko z wyższej konieczności. Jeden $\mathrm{z}$ moich informatorów mówił, że ma to być ogłoszone na trzy tygodnie. Kolejna informacja, którą tutaj dostałem od innej osoby: ptaszki z kręgów rządowych ćwierkają, że w niedzielę odbędzie się orędzie prezydenta. W poniedziałek zostanie wydany zakaz przemieszczania się pomiędzy miastami. Będą strefy czerwona, pomarańczowa, zielona, poza czerwoną nikt się nie wydostanie. Zielona i żółta tylko uzasadnione przypadki. Kolega dzwonił do mnie teraz z innego miasta. Powiedział, że rzeczywiście cośs się dzieje, ponieważ w Giżycku dostali wezwanie wszyscy, którzy sążołnierzami na przepustce i poborowi. Poza tym rozmawiałem przed chwilą z człowiekiem, który wyjeżdżał z Warszawy. Był on na komisji złóż naturalnych i tam walczył w tej sprawie. Powiedział, że na rogatkach ustawiają blokady przygotowane do zablokowania [...].

Zanim przejdzie się bezpośrednio do rozważań, dlaczego powyższy komunikat mógł wydawać się wiarygodny dla tak licznych jego odbiorców, warto przypomnieć słowa Dolińskiego (2005: 12) odnoszące się do częstotliwości i skuteczności wpływu społecznego: „Ulegamy takim mniej lub bardziej subtelnym naciskom — dziesiątki, a może nawet setki razy dziennie. Często [...] praktycy wpływu społecznego stosują wobec nas oddziaływania łączące w łańcuchy wiele technik, co utrudnia obronę przed niepożądanym wpływem społecznym". Podobna sytuacja miała także miejsce w przypadku przytoczonej treści nagrania. Fałszywa informacja nie opierała się bowiem wyłącznie na jednej technice wpływu społecznego, lecz $\mathrm{z}$ łatwością wskazać można co najmniej dwie, które mogły przyczynić się do bezrefleksyjnego odbioru jej treści.

W pierwszej kolejności podkreślić należy posługiwanie się autorytetami. Jak pisze Doliński (2005: 41): „o uznaniu kogoś za autorytet decyduje często wiedza o jego pozycji zawodowej. Wiemy o kimś, że jest fachowcem w określonej dziedzinie czy wybitnym znawcą jakiegoś zagadnienia”. Zasada ta znajduje zastosowanie poprzez wymienienie rzekomych źródeł informacji: koleżanka dziennikarka, ludzie blisko rządu, ABW i ONZ, urzędnicy państwowi, osoba na stanowisku kierowniczym. Choć wszystkie te określania po dokładniejszym przyjrzeniu się sprawiają wrażenie dosyć ogólnych i nieprecyzyjnych, bez odpowiedniej refleksji 
i krytycyzmu silnie wpływają na wiarygodność przekazu. W dynamicznie zmieniającej się sytuacji pandemii, a także w związku z działaniem licznych stresorów jej towarzyszących, informacja od dziennikarki oraz osób, których pozycja zawodowa jednoznacznie kojarzy się z władzą (komponentem autorytetu), nie budzi podejrzeń i staje się pożądaną odpowiedzią na nasiloną potrzebę poznania.

Kolejnym zabiegiem podnoszącym wiarygodność nagrania w oczach odbiorcy jest odwołanie się nie do jednego, lecz licznych źródeł informacji. Być może gdyby doniesienia autor fake newsa przypisał wyłącznie „koleżance dziennikarce” lub „koledze dzwoniącemu z innego miasta”, więcej odbiorców zachowałoby czujność i refleksyjność w odbiorze. Poprzez wymienienie jednak tak wielu pozornie niezależnych źródeł i odwołanie się do społecznego dowodu słuszności, fałszywa informacja wzorcowo wręcz uruchomiła automatyczne taśmy i zadziałała zgodnie z zasadą klik..., wrr... (Cialdini 2003). Reguła ta, jak opisuje sam Cialdini, zdaje się najsilniejsza, kiedy pochodzi od wielu różnych osób. Badacz dodaje także: „najbardziej skłonni jesteśmy uznać działania innych za dowód słuszności wtedy, gdy jesteśmy niepewni swego, gdy sytuacja jest niejasna i dwuznaczna, gdy króluje niepewność" (Cialdini 2003: 122). Choć dziś wiadomo, że przewidywania związane z zamknięciem miast i województw czy wprowadzeniem stanu wyjątkowego okazały się zupełnie niezgodne z prawdą, poprzez odwołanie nie tylko do jednego autorytetu, lecz także licznych źródeł, które rzekomo potwierdziły takie informacje, wskazany fake news okazał się skutecznie wprowadzić popłoch i dezinformację u wielu jego odbiorców.

\section{Ciepła woda, sauna i alkohol, czyli domowe sposoby na koronawirusa}

Szczególnie w początkowych tygodniach pandemii bardzo wyraźny był chaos informacyjny. Wirus dla wszystkich był czymś nowym, nie do końca zbadanym i zrozumiałym, a wiedza na jego temat ciągle była zgłębiana (Penkala-Gawęcka 2020). Efektem tego okazały się liczne sprzeczne komunikaty i zalecenia związane ze środkami bezpieczeństwa w trakcie pandemii. Sam Minister Zdrowia początkowo krytycznie wypowiadał się o skuteczności maseczek, niedługo później wprowadzony został odgórny nakaz ich noszenia (Świdrak 2020). Gdy więc takie nieścisłości zaczęły padać z ust autorytetów, ludzie rozpoczęli poszukiwania informacji w innych źródłach. Tak jak w przypadku innych fake newsów i tym razem takie komunikatory jak WhatsApp i Messenger okazały się narzędziem natychmiastowej odpowiedzi na ludzką potrzebę poznania. Tak rozpoczęło się rozsyłanie internetowych „łańcuszków” z wszelkiego rodzaju poradami zdrowotnymi (O’Connor i Murphy 2020).

Polecane domowe sposoby na zwalczenie koronawirusa były najróżniejsze. Jako najciekawsze wymienić można jak najczęstsze picie ciepłej wody, która rzekomo miałaby spłukiwać wirusa z gardła do żołądka, gdzie następnie zabijany byłby przez kwas żołądkowy (Grovett 2020), częste wizyty w saunie, której ciepło miałoby zwalczyć wirusa (Rzymski 2020), a także spożywanie alkoholu, który analogicznie do środków do dezynfekcji dłoni miałby „zdezynfekować” organizm od środka (WHO 2020; Mehrpour i Sadeghi 2020). Żadna z tych metod nie znalazła naukowego potwierdzenia, a także nie była zalecana ze strony lekarzy, więc tym bardziej warto zastanowić się, dlaczego tak wiele osób z łatwością w nie wierzyła i stosowała owe sposoby.

Odpowiedzią na to pytanie może być technika wpływu społecznego związana z lubieniem i sympatią. Reguła ta mówi, że łatwiej ulega się wpływowi ze strony znanych sobie osób, które dodatkowo darzy się pozytywnymi uczuciami — „Z reguły bardziej lubimy to, co znamy” 
(Cialdini 2003: 162). Tłumaczy to więc, dlaczego szybciej wierzy się w treść takich porad, jeśli przesyłane są one przez przyjaciół, znajomych z pracy czy rodzinę. Dodatkowo, jeśli ów łańcuszek przesłany będzie jednocześnie przez kilka bliskich osób, a jest to specyfika właśnie tego rodzaju wiadomości, zadziała także reguła społecznego dowodu słuszności, która jeszcze bardziej zwiększy zaufanie wobec fake newsa.

Przypadek tychże fałszywych informacji jednak nie jest tak prosty, jak mogłoby się wydawać na pierwszy rzut oka. Choć rzeczywiście wytłumaczenie znajduje w regule lubienia i sympatii oraz społecznego dowodu słuszności, to opozycyjne stanowisko zajmują jednak lekarze, którzy zgodnie z zasadą autorytetu powinni wszak być wiarygodnym źródłem informacji. Wyjaśnienia tej anomalii można doszukać się w ciekawych wynikach badań brytyjskiego serwisu badania opinii publicznej YouGov. Uzyskano je w maju 2020 roku i ukazują, że spośród 26 krajów jedynie w Polsce zaufanie wobec rodziny i przyjaciół deklaruje się jako większe w porównaniu z zaufaniem wobec personelu medycznego (healthcare professionals) (Smith 2020). Konsekwencją tego może być większa skłonność do wcielania w życie porad pochodzących właśnie od bliskich osób niż zaleceń lekarskich, które potwierdzenie miałyby w badaniach naukowych.

\section{Trump i „chińska zaraza”}

Nie ulega wątpliwości, że krajem, który — przynajmniej na ten moment — najbardziej dotkliwie odczuł skutki pandemii koronawirusa, są Stany Zjednoczone (Yadav 2021). Liczba zgonów spowodowanych zachorowaniem na COVID-19 wynosi tam ponad 560 tysięcy, co równe jest niemalże jednej piątej wszystkich zgonów związanych z pandemią na świecie (CDC 2021). Jak wskazują badania opinii publicznej przeprowadzone w sierpniu ubiegłego roku przez Monmouth University Polling Institute (2020) ponad połowa Amerykanów (52\%) uważała, że Stany Zjednoczone na tle innych państw zdecydowanie gorzej radzą sobie w zwalczaniu koronawirusa, a aż $72 \%$ stwierdziło, że sytuacja zmierza w złym kierunku.

Takie nastroje były szczególnie niekorzystne dla prezydenta Trumpa w świetle zbliżających się wyborów prezydenckich, które odbyły się w listopadzie 2020 roku. Dla złagodzenia napięcia spowodowanego stale pogarszającymi się doniesieniami związanymi z pandemią Trump zastosował technikę reorientacji, którą Witkowski opisuje następująco:

Szukanie kozła ofiarnego, bo taki jest sens i istota reorientacji, to jeden z najbardziej popularnych sposobów radzenia sobie głównie w sytuacji konfliktowej. Wskazanie winnego i skierowanie na niego biorących udział w konflikcie to według mniemania wielu ludzi bardzo skuteczna metoda radzenia sobie w sytuacjach konfliktowych. W polityce czy w zarządzaniu bardzo często stosuje się tę metodę dla uspokojenia niezadowolonych grup społecznych lub pracowników.

Pytany o radzenie sobie z sytuacją pandemii Trump w licznych wypowiedziach rutynowo zamiast określenia „koronawirus” lub „COVID-19” posługiwał się zwrotem „the China virus”, który tłumaczyć można jako „chiński wirus” lub „chińska zaraza” (Reny i Barreto 2020; 
Tessler, Choi i Kao 2020). Podkreślał także, że Chiny należy pociągnąć do odpowiedzialności za „wypuszczenie wirusa w świat” (Macias 2020).

Choć określenia stosowane przez Donalda Trumpa nie stanowią fake newsów samych w sobie, to podręcznikowo wręcz wpisują się w przytoczoną już wcześniej definicję dezinformacji: „istotą dezinformacji jest prowokacja, a nie kłamstwo [...]; państwa używają swych wywiadów do malowania obrazu prowokującego przeciwnika do podejmowania błędnych ocen" (Świerczek 2017: 211). Warto także pamiętać przy tym o wspomnianej wcześniej technice wpływu społecznego związanej z autorytetem, w którą wpisują się liczne komponenty władzy obserwowane u osoby pełniącej stanowisko prezydenta Stanów Zjednoczonych. Reorientacja stosowana zatem przez osobę na stanowisku najwyższej władzy, a tym samym przerzucanie odpowiedzialności za pandemię na Chiny w oczach wielu Amerykanów może być wiarygodne i chętnie powielane.

\section{Szczepionki z chipami}

Wraz z rozpoczęciem pandemii i skrajnym ograniczeniem wielu dziedzin życia najbardziej wyczekiwanym rozwiązaniem była wizja wynalezienia szczepionki przeciwko COVID-19. Gdy jednak w drugiej połowie 2020 roku firma Pfizer ogłosiła, że taka niebawem się pojawi, liczba coraz to nowszych fałszywych informacji związanych ze szczepieniami zaczęła rosnąć w zawrotnym tempie. W internecie natychmiast przeczytać można było komentarze, że specyfik z pewnością nie mógł w takim czasie przejść wszystkich wymaganych testów i może być niebezpieczny (Thelwall, Kousha i Thelwall 2021). Część internautów przekonana była także, że szczepionki mają zawierać chipy, które pozwoliłyby na śledzenie położenia osoby, która by je przyjęła oraz wykradania informacji na jej temat (Thelwall, Kousha i Thelwall 2021; Zieleniewska 2021). W kilku polskich miastach na ulicach odbyły się nawet pochody osób przebranych w kombinezony ochronne zakładane przez służby medyczne na oddziałach zakaźnych, a uczestnicy nieśli trumnę z podpisem „zaszczepieni” (Jarczok 2021; Kokoszkiewicz 2021). Takie makabryczne widoki oraz wszelkie krytyczne komentarze dotyczące szczepionek odbiły się mocno na stosunku Polaków wobec szczepień przeciwko COVID-19. Wyniki badania przeprowadzonego w listopadzie 2020 roku przez Centrum Badania Opinii Społecznej wskazały, że zaledwie 36\% Polaków deklaruje chęć przyjęcia szczepionki, a aż 69\% obawia się niepożądanych efektów ubocznych.

Choć wyniki te wydają się wyjątkowo pesymistyczne w perspektywie walki z pandemią, bardzo interesujący mechanizm społeczny zaobserwować można było na początku 2021 roku. Narodowy program szczepień rozpoczął się 27 grudnia i w pierwszej kolejności zaszczepione miały być osoby z tak zwanej "grupy zero”, do której należał przede wszystkim personel medyczny, a więc ci, którzy najbardziej narażeni są na zarażenie koronawirusem (Ważna 2021). Już w pierwszych dniach stycznia 2021 roku nagłośniona została jednak sytuacja, która miejsce miała w Warszawskim Uniwersytecie Medycznym. Upublicznione zostały informacje, że wraz z „grupą zero”, począwszy od 29 grudnia, zaszczepionych zostało także wielu polskich celebrytów. Wśród osób, które przyjęły szczepienie, wymienia się nazwiska znane z telewizji, sceny teatralnej czy politycznej (Makarewicz 2021; Zubik 2021). Co ciekawe, wyniki badania Centrum Badania Opinii Społecznej przeprowadzanego w dniach od 4 do 14 stycznia 2021 roku, a więc bezpośrednio po nagłośnieniu zajścia na Warszawskim Uniwersytecie Medycznym, wskazały, że chęć przyjęcia szczepionki zadeklarowało już 56\% Polaków. 
Zjawisko to można próbować wytłumaczyć poprzez odwołanie reguły niedostępności, którą Doliński (2005) określa jako potężne narzędzie wpływu społecznego. Jak pisze Cialdini (2003: 229): „nie tylko bardziej pożądamy jakiegoś dobra, gdy staje się ono niedostępne - pożądamy go najbardziej wtedy, gdy niedostępność wynika z pożądania danego dobra przez innych ludzi”. W tym przypadku więc chęć zaszczepienia przez niektóre znane osoby sprawiła, że dla innych stało się ono tym bardziej atrakcyjne, że sami nie mieli możliwości pozyskania szczepionki. Poza dominującą regułą niedostępności można zatem zauważyć także wpływ autorytetu. Ponadto w związku z ogłoszonym niedługo później komunikatem firmy Pfizer o planowanym zmniejszeniu liczby szczepionek (PolsatNews 2021) podejrzewać można, że deklarowana chęć zaszczepienia się będzie nadal rosnąć, ponieważ, jak tłumaczy Cialdini (2003: 210): „Zagrożenie potencjalną utratą odgrywa dużą rolę przy podejmowaniu decyzji”. Podkreśla także, że zagrożenie to „odgrywa szczególną rolę w warunkach ryzyka i niepewności” (Cialdini 2003: 210). Im bardziej ograniczone zostanie zatem przyjmowanie zapisów na szczepienia, wynikające z ograniczonej dostępności produktu, tym więcej osób będzie chętnych na jego przyjęcie. W tym wyjątkowym przypadku zatem można powiedzieć, że techniki wpływu społecznego, zamiast zwiększać negatywne skutki fake newsów, zadziałały w odwrotny sposób.

\section{Zagrożenia płynące $\mathrm{z}$ fake newsów}

Ponieważ konsekwencje fałszywych informacji zależą przede wszystkim od treści danego fake newsa i jego rozpowszechnienia, spektrum wynikających z nich zagrożeń jest ogromne - począwszy od zupełnie błahych, a skończywszy na wręcz śmiertelnie niebezpiecznych (Sciortino 2020). Szulc (2020) zwraca uwagę na istotne statystyki związane z tymi „alternatywnymi faktami”: „Dla 99\% Polaków w wieku 16-24 lat internet jest głównym źródłem informacji, a najchętniej odwiedzanymi stronami są Facebook i YouTube. Badania brytyjskie pokazują, że uczniowie szkół podstawowych znacznie gorzej niż uczniowie szkół średnich zdają sobie sprawę ze zjawiska fake newsów. A nawet ci, którzy mają jakąś wiedzę na ten temat, nie zawsze są w stanie jej skutecznie rozpoznawać” (Szulc 2020: 148). Tym samym podkreśla narażenie na ekspozycję na fake newsy szczególnie wśród młodych osób.

Przyglądając się pierwszemu ze wskazanych wyżej fake newsów, trudno dopatrzeć się potencjalnie śmiertelnie szkodliwych skutków. Wprowadza on dezinformację, która z kolei skutkować może jeszcze bardziej zwiększonym lękiem przed nieznanym (Banerjee i Rao 2020). Podobnie zalecenie związane z piciem wody czy korzystaniem z sauny. Choć nawet najczęstsze picie ciepłych płynów z pewnością nie zwalczy koronawirusa (Khadka, Hashmi i Usman 2020), to nie powinno ono negatywnie odbić się na zdrowiu (Cheng, Cheng i Zou 2020). Wizyty w saunie z kolei analogicznie nie okażą się pomocne w przypadku aktywnego zarażenia SARS-CoV-2, jednak mogą wpłynąć na zwiększenie odporności, a także obniżenie stresu, co w kontekście pandemii może okazać się ważne (Cohen 2020; Kunutsor, Lavie i Laukkanen 2021).

Inaczej sytuacja wygląda jednak w przypadku przekazów, które dotyczą picia alkoholu w dużych ilościach, rozpowszechniania nieprawdziwych informacji na temat szczepionek przeciwko COVID-19 czy obarczania odpowiedzialnością za pandemię Chiny. Spożywanie alkoholu nie tylko nie zwalczy koronawirusa, lecz nadużywanie go z dużą częstotliwością może wręcz wpłynąć negatywnie na odporność i stan zdrowia (WHO 2020). W Stanach Zjednoczonych odnotowano także przypadki osób, które w celu „zabicia wirusa” decydowały 
się na picie środków przeznaczonych do dezynfekcji dłoni (Mehrpour, Sadeghi 2020; Yip i in. 2020). Takie zachowania wywołane wiarą w fake newsy mogą stanowić wręcz bezpośrednie zagrożenie życia, podobnie jak rezygnacja z przyjęcia szczepionki w obawie przed zawartym w niej chipem. Ponadto dezinformacja obwiniająca Chiny o epidemię przyczyniła się do ogromnego wzrostu rasizmu, mowy nienawiści, a nawet przejawów bezpośredniej przemocy fizycznej wobec osób pochodzenia azjatyckiego (van Bavel i in. 2020; Gover, Harper i Langton 2020; Reny i Barreto 2020; Tessler, Choi i Kao 2020). Wszystko to obrazuje, jak ogromne skutki może mieć rozpowszechnianie fałszywych informacji, szczególnie w sytuacji tak trudnej jak pandemia.

*Wiele okoliczności związanych z pandemią koronawirusa SARS-CoV-2 sprawia, że w obecnej sytuacji jesteśmy szczególnie narażeni na ekspozycję na fake newsy. Jako największe czynniki ryzyka wymienić można przede wszystkim liczne stresory, lęk oraz tempo napływających informacji. Ilość docierających bodźców wzmaga więc pokusę, by pewne zachowania odbywały się „na skróty”, zgodnie z zasadą klik..., wrr... Sama świadomość istnienia technik wpływu społecznego i ich działania może jednak okazać się pierwszym krokiem do demaskowania tychże „alternatywnych faktów”. Śledząc coraz to nowsze doniesienia związane z COVID-19, warto pamiętać o tym, jak ważna jest refleksja nad ich treścią i źródłem, która uchronić może wiele osób przed potencjalnie groźnymi skutkami fake newsów i dezinformacji.

\section{ZUZANNA SCHNEIDER}

Studentka psychologii na Uniwersytecie Śląskim w Katowicach. Od trzeciego roku studiów realizuje ścieżki specjalizacji psychologii klinicznej i psychologii sądowej. Uczestniczy w zespolach badawczych zajmujących się badaniem szeroko pojętych związków psychologii z filmem, a także roli kontaktu zdalnego i związków izolacji towarzyszącej pandemii COVID-19 z dobrostanem psychicznym i poczuciem samotności. Do głównych zainteresowań badawczych zalicza psychologię społeczną i zaburzenia osobowości. Uniwersytet Śląski w Katowicach, Wydział Nauk Społecznych, ul. Grażyńskiego 53, 40-126 Katowice 


\section{Bibliografia}

Alvi Irum, Saraswat Niraja (2020), Information Processing - Heuristic vs Semantic and Susceptibility of Sharing COVID-19-Related Fake News on Social Media, "Journal of Content, Community \& Communication”, nr 12, s. 42-56.

Antos Gerd (2019), Fake news. Dlaczego im ulegamy. Albo: „Urzadzę wam świat tak, jak mi sie podoba”, "Tekst i dyskurs - Text und Dyskurs”, nr 12, s. 191-213.

Aronson Elliot, Wilson Timothy D., Akert Robin M. (1995), Psychologia spoteczna. Serce i umyst, Wydawnictwo Zysk i S-ka, Poznań.

Banerjee Debanjan, Rao Sathyanarayana T.S. (2020), Psychology of Misinformation and the Media: Insights from the COVID-19 Pandemic, „Indian Journal of Social Psychiatry”, nr 36(5), s. 131-137.

van Bavel Jay J., Baicker Kathrine, Boggio Paulo S., Capraro Valerio, Cichocka Aleksandra, Cikara Mina, Crockett Molly J., Crum Alia J., Douglas Karen M., Druckman James N., Drury John, Dube Oeindrila, Ellemers Naomi, Finkel Eli J., Fowler James H., Gelfand Michele, Han Shihui, Haslam S. Alexander, Jetten Jolanda, Kitayama Shinobu, Mobbs Dean, Napper Lucy E., Packer Dominic J., Pennycook Gordon, Schnall Simone, Shariff Azim, Skitka Linda J., Smith Sandra Susan, Sunstein Cass R., Tabri Nassim, Tucker Joshua A., van der Linden Sander, van Lange Paul, Weeden Kim A., Wohl Michael J. A., Zaki Jamil, Zion Sean R., Willer Robb (2020), Using Social and Behavioural Science to Support COVID-19 Pandemic Response, „Nature Human Behavior”, nr 4(5), s. 460-471.

Bąkowicz Katarzyna (2019), Wprowadzenie do definicji i klasyfikacji zjawiska fake newsa, „Studia Medioznawcze", t. 20, nr 3(78), s. 280-289.

Bieniek Barbara (2020), Między prawda a fake new'em. Dezinformacja w czasie pandemii koronawirusa [w:] Państwo i prawo w czasach COVID-19, red. Stępniak K., Wydawnictwo Think\&Make, Warszawa, s. 433-456.

CBOS (2021), Wzrost zainteresowania szczepieniami przeciwko COVID-19, Warszawa.

CDC (2021), COVID Data Tracker, https://covid.cdc.gov/covid-data-tracker/\#datatracker-home [dostęp: 27.04.2021].

Cheng Kang, Cheng Vivien, Zou Changhua (2020), Hemodynamics of Maintaining Transportation of All Nutrients in Blood Flowing: Drinking (Boiled) Warm Water and Complete Nutrition Fluids for Primary and Secondary Prevention of Coronavirus Disease 2019 in Clinic, „Clinical Research in Hematology”, nr 3(2), s. 1-5.

Cialdini Robert (2003), Wywieranie wptywu na ludzi. Teoria i praktyka, GWP, Gdańsk.

Cohen Marc (2020), Turning up the Heat on COVID-19: Heat as a Therapeutic Intervention, „F1000Research”, nr 9, s. 292.

Cuan-Baltazar Jose Yunam, Muñoz-Perez Maria José, Robledo-Vega Carolina, Pérez-Zepeda Maria Fernanda, Soto-Vega Elena (2020), Misinformation of COVID-19 on the Internet: Infodemiology Study, ,JMIR Public Health and Surveillance”, nr 6(2).

Doliński Dariusz (2005), Techniki wptywu spotecznego, Wydawnictwo Naukowe Scholar, Warszawa.

Gover Angela R., Harper Shannon B., Langton Lynn (2020), Anti-Asian Hate Crime During the COVID-19 Pandemic: Exploring the Reproduction of Inequality, „American Journal of Criminal Justice", nr 45(4), s. 647-667. 
Greene Ciara, Murphy Gillian (2020), Individual Differences in Susceptibility to False Memories for COVID-19 Fake News, „Cognitive Research: Principles and Implications”, nr 5(1), s. 1-8.

Grovett Zaria (2020), No, Drinking Water Doesn't Kill Coronavirus, www.bbc.com/future/ article/20200319-covid-19-will-drinking-water-keep-you-safe-from-coronavirus [dostęp: 27.04.2021].

Iwasiński Łukasz (2018), Fake news i post-prawda. Krótka charakterystyka, „Przegląd edukacyjny", nr 2, s. 2-4.

Jarczok Artur (2021), Marsz niewolników i pogrzeb „zaszczepionych” w Cieszynie - wideo i zdjęcia, https://beskidzka24.pl/marsz-niewolnikow-i-pogrzeb-zaszczepionych-w-cieszyniezdjecia/ [dostęp: 27.04.2021].

Jaśkowiec Michał (2020), Fake news w dobie pandemii COVID-19 [w:] Państwo i prawo w czasach COVID-19, red. Stępniak K., Wydawnictwo Think\&Make, Warszawa, s. 456-477.

Khadka Sitaram, Hashmi Furqan K., Usman Muhammad (2020), Preventing COVID-19 in Low-And Middle-Income Countries, „Drugs \& Therapy Perspectives”, nr 36(6), s. 250-252.

Kokoszkiewicz Mateusz (2021), Koronasceptycy $i$ narodowcy protestowali we Wroctawiu przeciwko „plandemii”, policji i szczepieniom, https://wroclaw.wyborcza.pl/wroclaw/7,35771,26811747,antycovidowcy-protestowali-przeciwko-plandemii-i-szczepieniom.html [dostęp: 27.04.2021]

Kossowska Małgorzata (2003), Różnice indywidualne w potrzebie poznawczego domknięcia, „Przegląd Psychologiczny”, t. 46, nr 4, s. 355-373.

Król Mieczysław Jan, Trybuła Joanna (2019), Internet w życiu mtodzieży licealnej — statystyczna analiza na podstawie badania ankietowego, „Nierówności społeczne a wzrost gospodarczy”, nr 58, s. 312-328.

Kunutsor Setor K., Lavie Carl J., Laukkanen Jari A. (2021), Finnish Sauna and COVID-19, „Le Infezioni in Medicina”, t. 29(1), s. 160-162.

Landucci Francesco, Lamperti Massimo (2020), A Pandemic of Cognitive bias, „Intensive Care Medicine", nr 47(5), s. 636-673.

van der Linden Sander, Roozenbeek Jon, Compton Josh (2020), Inoculating Against Fake News About COVID-19, „Frontiers in psychology”, nr 11, s. 566-790.

Macias Amanda (2020), Trump Urges UN to Hold China Accountable for the Coronavirus Pandemic, www.cnbc.com/2020/09/22/trump-urges-un-to-hold-china-accountable-for-coronavirus-pandemic.html [dostęp: 27.04.2021].

Makarewicz Nicole (2021), Szczepienia poza kolejnościa na WUM. Zawiadomienie wptynęto do prokuratury, www.rmf24.pl/raporty/raport-program-szczepien-przeciw-covid/news-szczepienia-poza-kolejnoscia-na-wum-zawiadomienie-wplynelo-d,nId,4980049 [dostęp: 27.04.2021].

Mehrpour Omid, Sadeghi Mahmood (2020), Toll of Acute Methanol Poisoning for Preventing COVID-19, „Archives of Toxicology”, nr 94(6), s. 2259-2260.

Monmouth University Polling Institute. (2020), US Not Handling Covid As Well As Other Countries, www.monmouth.edu/polling-institute/documents/monmouthpoll_us_081320. pdf/ [dostęp: 29.01.2021].

Moscadelli Andrea, Albora Giuseppe, Biamonte Massimiliano Alberto, Giorgetti Duccio, Innocenzio Michele, Paoli Sonia, Lorini Chiara, Bonanni Paolo, Bonaccorsi Guglielmo (2020), Fake News and Covid-19 in Italy: Results of a Quantitative Observational Study, „International Journal of Environmental Research and Public Health", t. 17(16). 
Naeem Salman Bin, Bhatti Rubina (2020), The Covid-19 'Infodemic': a New Front for Information Professionals, „Health Information \& Libraries Journal”, nr 37(3), s. 233-239.

Nanotkar Leena, Dhanvij Sneha, Joshi Abhishek (2020), COVID-19 and Importance of Social Distancing, "Journal of Critical Reviews", nr 7(8), s. 1103-1104

O'Connor Cathal, Murphy Michelle (2020), Going Viral: Doctors Must Tackle Fake News in The COVID-19 Pandemic, „BMJ (Clinical research ed.)”, nr 369, m1587.

Orzeł Karol (2020), Stan wyjątkowy? To fatszywe nagranie z marca 2020, fakenews.pl/spoleczenstwo/stan-wyjatkowy-to-falszywe-nagranie-z-marca-2020/ [dostęp: 16.04.2021].

Palczewski Marek (2019), Dyskurs ,fake newsa”, „Studia de Cultura”, t. 11, nr 1, s. 15-31.

Penkala-Gawęcka Danuta Maria (2020), COVID-19, niepewność, lęk i nadzieja. W poszukiwaniu skutecznego leku, „Lud”, nr 104.

PolsatNews (2021), Koronawirus. Pfizer tymczasowo zmniejsza dostawy dla Europy, www.polsatnews.pl/wiadomosc/2021-01-15/pfizer-tymczasowo-zmniejsza-dostawy-szczepionek-dlaeuropy/ [dostęp: 26.04.2021].

Qian Meirui, Jiang Jianli (2020), COVID-19 and social distancing, „Zeitschrift fur Gesundheitswissenschaften $=$ Journal of public health", Advance online publication. s. 1-3, DOI: 10.1007/s10389-020-01321-z.

Reny Tyler T., Barreto Matt A. (2020), Xenophobia in the Time of Pandemic: Othering, Anti-Asian Attitudes, and COVID-19, „Politics, Groups, and Identities”, s. 1-24.

Rzymski Piotr (2020), Koronawirus SARS-CoV-2. Fakty, a nie mity, www.polityka.pl/tygodnikpolityka/nauka/1945626,1,koronawirus-sars-cov-2-fakty-a-nie-mity.read [dostęp: 27.04.2021].

Sciortino Antonella (2020), Fake news and infodemia at the time of COVID-19, „Direito Público", t. 17 , nr 94, s. 35-49.

Smith Matthew (2020), International COVID-19 tracker, update: 18 May. YouGov, yougov. co.uk/topics/international/articles-reports/2020/05/18/international-covid-19-tracker-update-18-may?fbclid=IwAR2YiVEoSOJLSyV5qTWd6C81 nkg1kVsdEsiMbIaKd1xYRIj BmayYHzcf7gM [dostęp: 29.01.2021].

Szulc Marcin (2020), Manipulowanie informacja w sieci za pomoca fake newsów jako zagrożenie dla mtodzieży, „Psychologia Wychowawcza”, nr 59(17), s. 140-158.

Świdrak Karolina (2020), Dlaczego Ministerstwo Zdrowia zmienito zdanie w sprawie maseczek?, www.medonet.pl/koronawirus-pytania-i-odpowiedzi/jak-sie-chronic,dlaczego-ministerstwozdrowia-zmienilo-zdanie-w-sprawie-maseczek-,artykul,60854550.html [dostęp: 27.04.2021].

Świerczek Marek (2018), „System matrioszek”, czyli dezinformacja doskonata. Wstęp do zagadnienia, „Przegląd Bezpieczeństwa Wewnętrznego”, t. 10, nr 19, s. 210-228.

Tessler Hannah, Choi Meera, Kao Grace (2020), The Anxiety of Being Asian American: Hate Crimes and Negative Biases During the COVID-19 Pandemic, "American Journal of Criminal Justice", nr 45(4), s. 636-646.

Thelwall Mike, Kousha Kayvan, Thelwall Saheeda (2021), Covid-19 Vaccine Hesitancy on English-language Twitter, „Profesional de la Información (EPI)”, nr 30(2).

Troisi Alfonso (2020), Fear of COVID-19: Insights from Evolutionary Behavioral Science, „Clinical Neuropsychiatry", nr 17(2), s. 72-75.

Ważna Magda (2021), Kolejność szczepień przeciw COVID-19. Sprawdź, do której grupy należysz. [Wyjaśniamy], www.medonet.pl/porozmawiajmyoszczepionce/szczepionka-na-covid19,kolejnosc-szczepien-na-covid-19--sprawdz--do-ktorej-grupy-nalezysz--wyjasniamy,artykul,33076512.html [dostęp: 27.04.2021]. 
WHO (2020), Alcohol and COVID-19: What You Need to Know, www.euro.who.int/_data/ assets/pdf_file/0010/437608/Alcohol-and-COVID-19-what-you-need-to-know.pdf [dostęp: 26.04.2021].

Witkowski Tomasz (2000), Psychomanipulacje. Jak je rozpoznawać i jak sobie z nimi radzić, Unus, Wałbrzych.

Wojciszke Bogdan (2011), Psychologia spoteczna, Wydawnictwo Naukowe Scholar, Warszawa. Yadav Navdeep (2021), These are the 10 Most-Affected Countries with the Highest Number of COVID-19 Cases, www.businessinsider.in/politics/india/news/check-out-the-10-mostaffected-countries-with-the-highest-number-of-coronavirus-cases/slidelist/76275918.cms [dostęp: 27.04.2021].

Yip Luke, Bixler Danae, Brooks Daniel E., Clarke Kevin R., Deblina Datta S., Dudley Steven Jr., Komatsu Kenneth K., Lind Jennifer N., Mayette Annaliese, Melgar Michael, Pindyck Talia, Schmit Kristine M., Seifert Steven A., Shirazi Farshad Mazda, Smolinske Susan C., Warrick Brandon J., Chang Arthur (2020), Serious Adverse Health Events, Including Death, Associated with Ingesting Alcohol-Based Hand Sanitizers Containing Methanol - Arizona and New Mexico, May-June 2020, „Morbidity and Mortality Weekly Report”, nr 69(32), s. 1070-1073, DOI: 10.15585/MMWR.MM6932E1.

Zarocostas John (2020), How to Fight an Infodemic, „The Lancet”, nr 395(10225), s. 676.

Zieleniewska Monika (2021), Opublikowano sktad szczepionek przeciwko COVID-19. Nie ma tam mikrochipów, www.medonet.pl/porozmawiajmyoszczepionce,mikrochipow-nie-ma-wskladzie-szczepionek-na-koronawirusa,artykul,84648903.html [dostęp: 27.04.2021].

Zubik Małgorzata (2021), Burza po szczepieniach na WUM. Ludzie dziwiq sie, dlaczego szczepionki dostali Janda i Miller, warszawa.wyborcza.pl/warszawa/7,54420,26652847,burza-po-szczepieniach-wum-ludzie-dziwia-sie-dlaczego-szczepionki.html [dostęp: 27.04.2021].

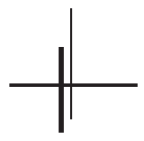

